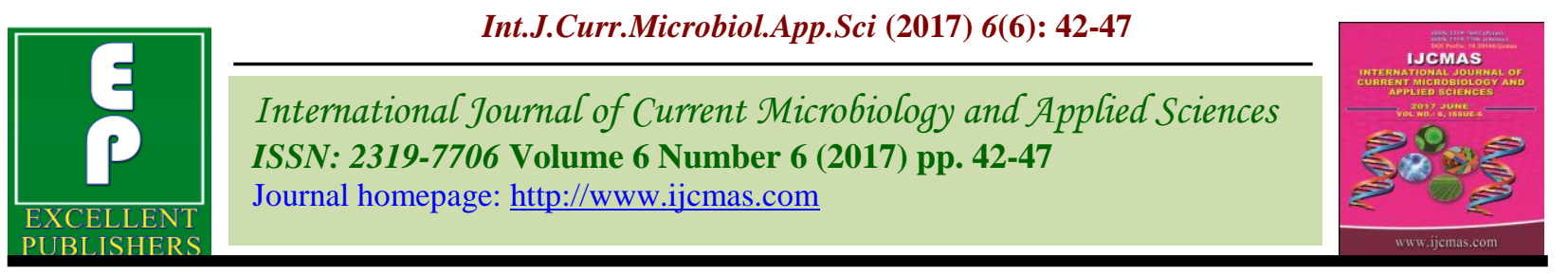

Original Research Article

https://doi.org/10.20546/ijcmas.2017.606.004

\title{
Variability, Heritability and Genetic Advance in Brinjal (Solanum melongena L.)
}

\author{
B. Ravali ${ }^{1}$, K. Ravinder Reddy ${ }^{1}$, P. Saidaiah ${ }^{2^{*}}$ and N. Shivraj ${ }^{3}$ \\ ${ }^{1}$ Department of Vegetable Science, College of Horticulture, Sri Konda Laxman Telangana State \\ Horticulture University, Rajendranagar, Hyderabad-500030, Telangana, India \\ ${ }^{2}$ Department of Genetics and Plant Breeding, SKLTSHU, Rajendranagar, \\ Hyderabad-500030, Telangana, India \\ ${ }^{3}$ Economic Botany, NBPGR Regional Station, Rajendranagar, \\ Hyderabad-500030, Telangana, India \\ *Corresponding author
}

A B S T R A C T

Thirty five accessions of brinjal were assessed for variability for nineteen

Keywords characters. Highly significant differences were observed among the

Brinjal,

Variability,

Heritability,

Genetic advance.

Article Info

Accepted:

04 May 2017

Available Online:

10 June 2017 accessions. High phenotypic and genotypic coefficient of variation was observed for number of fruits per cluster, number of fruits per plant, fruit length, fruit width, average fruit weight, fruit yield per plant, ascorbic acid content, total phenol content, shoot and fruit borer infestation indicating the existence of wider genetic variability for these traits in the germplasm. High heritability accompanied with high genetic advance was noticed for days to $50 \%$ flowering, number of flower clusters per plant, number of flowers per cluster, number of fruits per cluster, number of fruits per plant, days to last harvest, fruit length, fruit width, average fruit weight, fruit yield per plant, total phenol content, shoot and fruit borer infestation suggesting that they can be improved through direct selection due to predominant additive variation.

\section{Introduction}

Brinjal (Solanum melongena L.) is an important and popular vegetable crop of family Solanaceae, grown throughout the year all over the country. Eggplant contains the alkaloid solanine in roots and leaves, and there are medicinal uses for eggplant. Fruits are rich in $\mathrm{Ca}, \mathrm{Mg}$, and $\mathrm{P}$ and contain fatty acids (Dhankhar and Singh, 1984). Being primary centre of origin, India has accumulated a wide range of variability in this crop. Genetic improvement of any crop mainly depends on the amount of genetic variability present in the population and the germplasm serves as a valuable source of base population and provide scope for wide variability (Gavade and Ghadage, 2015). Further, the crop exhibits rich genetic diversity and scope for improvement for 
various horticultural traits. Heritability is the heritable portion of phenotypic variance. The estimates of heritability help the plant breeder in selection of elite genotypes from diverse genetic populations. Heritability indicates only the effectiveness with which selection of a genotype can be based on phenotypic performance but it fails to indicate the expected genetic progress in one cycle of selection. Heritable variation can be effectively used with greater degree of accuracy when heritability is studied in conjunction with genetic advance (Johnson et al., 1955). Genetic advance denotes the improvement in the mean genotypic values of selected families over base population and thus helps the breeder to select the progenies in the earlier generation itself. An improvement in yield and quality of brinjal is normally achieved by selecting the genotypes with desirable character combination existing in nature or by hybridization. With this objective, the present investigation was carried out with brinjal germplasm.

\section{Materials and Methods}

Thirty-five brinjal germplasm lines were evaluated in Randomized Block Design with three replications. The experiment was carried out at Vegetable Research Block, SKLTSHU, Rajendra nagar, Hyderabad during rabi seasons of 2015-16. Thirty days old seedlings from the nursery beds were transplanted on ridges adopting a spacing of $50 \mathrm{~cm} \times 50 \mathrm{~cm}$. twenty plants of each genotype were maintained in a plot in each replication. Recommended cultural practices were followed. Observations were recorded from five randomly selected plants of each genotype in each replication. The data were analyzed by the methods of Cochran and Cox (1957) using mean values of random plants in each replication from all genotypes to determine significance of genotypic effects. Genotypic and phenotypic coefficients of variation were calculated using the formulae of Burton (1952). Broad sense heritability was calculated as per Lush (1940) and genetic advance estimated by the method of Johnson et al., (1955a). Categorization of genotypic coefficient of variation (GCV), phenotypic coefficient of variation (PCV) and genetic advance (GA) were done as per Sivasubramanian and Menon (1973) and heritability categorized as by Johnson et al., (1955).

\section{Results and Discussion}

The mean sum of squares for nineteen characters in genotypes of brinjal is presented in table 1. Analysis of variance revealed highly significant differences among genotypes for all nineteen characters. The results pertaining to mean, range, phenotypic coefficient of variation (PCV), genotypic coefficient of variation (GCV), heritability in broad sense (h2) and expected genetic advance as per cent of mean (GAM) for all the nineteen characters are furnished in table 2.

Variability refers to the presence of differences among the individuals of a population. Variability is essential for wide adaptability and resistance to biotic and a biotic factors and hence, an insight into the magnitude of genetic variability present in a population is of paramount important to a plant breeder for starting a judicious breeding programme. The phenotypic and genotypic variances measure the magnitude of variation arising out of difference in phenotypic and genotypic values. The absolute values of phenotypic and genotypic variances cannot be used for comparing the magnitude of variability for different characters, since the mean and units of measurement of the characters may be different. Hence, the coefficients of variation expressed at phenotypic and genotypic levels have been used. 
A relatively high estimate of genotypic and phenotypic coefficient of variation (GCV of more than $20 \%$ ) occurred for number of fruits per cluster, number of fruits per plant, fruit length, fruit width, average fruit weight, fruit yield per plant, ascorbic acid content, total phenol content, shoot and fruit borer infestation were high indicating the presence of high variability in the germplasm for selection. It could be inferred that the selection for improvement of these characters would be effective.

The results are in consonance with Kumar et al., (2011), Kumar et al., (2012), Lokesh et al., (2013), Arunkumar et al., (2013), Ramesh Kumar and Arumugam (2013), Gavade and Ghadage (2015). Moderate phenotypic and genotypic coefficients of variation (10-19\%) were observed for number of branches per plant, days to first flowering and days to $50 \%$ flowering. The parameters like number of flower clusters per plant and number of flowers per cluster exhibited moderate coefficient of variation at genotypic level. There is the opportunity for improving these characters in the desirable direction through selection. This agrees with findings of Ramesh Kumar and Arumugam (2013), Lokesh et al., (2013), Gavade and Ghadage (2015). Low estimates of phenotypic and genotypic coefficient of variation were observed for plant height, days to first fruit harvest and days to last fruit harvest. Similar results were reported by Kumar et al., (2012), Gavade and Ghadage (2015).

Table.1 Mean squares of the nineteen characters studied in brinjal

\begin{tabular}{|c|c|c|c|c|c|c|c|}
\hline S. No. & Character & $\begin{array}{c}\text { Replications } \\
(\mathrm{df}=\mathbf{2})\end{array}$ & $\begin{array}{c}\begin{array}{c}\text { Treatments } \\
(\mathbf{d f}=34)\end{array} \\
\end{array}$ & $\begin{array}{c}\text { Error } \\
(\mathrm{df}=68)\end{array}$ & S.E. & C.V. (\%) & C.D. 5\% \\
\hline 1 & Plant height $(\mathrm{cm})$ & 65.13 & $193.19 * *$ & 1.37 & 0.67 & 1.23 & 1.91 \\
\hline 2 & No. of branches per plant & 19.04 & $6.35 * *$ & 0.54 & 0.42 & 5.41 & 1.20 \\
\hline 3 & Days to first flowering & 38.37 & $117.25^{* *}$ & 0.69 & 0.48 & 1.95 & 1.36 \\
\hline 4 & Days to $50 \%$ flowering & 17.86 & $111.87 * *$ & 0.52 & 0.41 & 1.49 & 1.18 \\
\hline 5 & No. of flower clusters per plant & 35.87 & $32.76 * *$ & 0.64 & 0.46 & 4.56 & 1.30 \\
\hline 6 & No. of flowers per cluster & 2.96 & $1.04 * *$ & 0.15 & 0.22 & 13.64 & 0.64 \\
\hline 7 & No. of fruits per cluster & 2.98 & $0.69 * *$ & 0.07 & 0.15 & 14.82 & 0.44 \\
\hline 8 & No. of fruits per plant & 29.54 & $104.37 * *$ & 0.45 & 0.38 & 3.12 & 1.10 \\
\hline 9 & Days to first harvest & 32.86 & $110.76^{* *}$ & 0.77 & 0.51 & 1.39 & 1.44 \\
\hline 10 & Days to last harvest & 43.53 & $277.38 * *$ & 0.50 & 0.41 & 0.47 & 1.15 \\
\hline 11 & Fruit length $(\mathrm{cm})$ & 1.36 & $35.33 * *$ & 0.27 & 0.30 & 4.39 & 0.85 \\
\hline 12 & Fruit width $(\mathrm{cm})$ & 0.01 & $5.29 * *$ & 0.02 & 0.08 & 2.92 & 0.24 \\
\hline 13 & Average fruit weight $(\mathrm{kg})$ & 0.04 & $0.004 * *$ & 0.00 & 0.00 & 1.84 & 0.00 \\
\hline 14 & Fruit yield per plant $(\mathrm{kg})$ & 0.26 & $4.17 * *$ & 0.02 & 0.05 & 4.51 & 0.14 \\
\hline 15 & Ascorbic acid content $(\mathrm{mg} / 100 \mathrm{~g})$ & 0.10 & $6.12 * *$ & 17.68 & 0.08 & 2.37 & 0.24 \\
\hline 16 & Total phenol content $(\mathrm{mg} / 100 \mathrm{~g})$ & 17.65 & $570.67 * *$ & 2.65 & 2.42 & 8.97 & 6.86 \\
\hline 17 & Shoot and fruit borer infestation (\%) & 33.32 & $140.48 * *$ & 0.008 & 0.94 & 9.91 & 2.65 \\
\hline 18 & Cumulative wilt incidence (\%) & 0.00 & 0.00 & 0.00 & 0.00 & 0.00 & 0.00 \\
\hline 19 & Little leaf incidence $(\%)$ & 0.00 & 0.00 & 0.00 & 0.00 & 0.00 & 0.00 \\
\hline
\end{tabular}


Table.2 Estimates of variability, heritability and genetic advance as Percent of mean for nineteen characters

\begin{tabular}{|c|c|c|c|c|c|c|c|c|c|c|c|}
\hline \multirow[b]{2}{*}{ S.No } & \multirow[b]{2}{*}{ Characters } & \multicolumn{2}{|c|}{ Range } & \multirow[b]{2}{*}{ Mean } & \multicolumn{2}{|c|}{ Variance } & \multirow[b]{2}{*}{$\begin{array}{r}\text { PCV } \\
(\%)\end{array}$} & \multirow[b]{2}{*}{$\begin{array}{r}\text { GCV } \\
(\%)\end{array}$} & \multirow[b]{2}{*}{$\begin{array}{l}\mathbf{h}^{2} \\
(\%)\end{array}$} & \multirow[b]{2}{*}{$\begin{array}{l}\text { Genetic } \\
\text { Advance }\end{array}$} & \multirow{2}{*}{$\begin{array}{c}\text { GA as } \\
\text { per } \\
\text { cent of } \\
\text { mean } \\
\end{array}$} \\
\hline & & $\begin{array}{l}\text { Mini } \\
\text { mum }\end{array}$ & $\begin{array}{l}\text { Maxi } \\
\text { mum }\end{array}$ & & $\begin{array}{l}\text { Pheno - } \\
\text { typic }\end{array}$ & $\begin{array}{l}\text { Geno- } \\
\text { typic }\end{array}$ & & & & & \\
\hline 1 & Plant height $(\mathrm{cm})$ & 81.24 & 106.02 & 94.83 & 65.31 & 63.94 & 8.522 & 8.43 & 97.90 & 16.29 & 17.18 \\
\hline 2 & No. of branches per plant & 11.10 & 16.66 & 13.58 & 2.48 & 1.94 & 11.59 & 10.25 & 78.17 & 2.53 & 18.67 \\
\hline 3 & Days to first flowering & 32.55 & 54.33 & 42.7 & 39.55 & 38.85 & 14.72 & 14.59 & 98.23 & 12.72 & 29.80 \\
\hline 4 & Days to $50 \%$ flowering & 36.33 & 60.33 & 48.39 & 37.64 & 37.12 & 12.67 & 12.59 & 98.60 & 12.46 & 25.75 \\
\hline 5 & $\begin{array}{l}\text { No. of flower clusters per } \\
\text { plant }\end{array}$ & 10.99 & 26.22 & 17.53 & 11.35 & 10.71 & 19.21 & 18.66 & 94.34 & 6.54 & 37.33 \\
\hline 6 & No. of flowers per cluster & 1.66 & 4.11 & 2.88 & 0.45 & 0.30 & 23.28 & 18.87 & 65.66 & 0.90 & 31.50 \\
\hline 7 & No. of fruits per cluster & 1.00 & 2.88 & 1.85 & 0.28 & 0.21 & 28.60 & 24.46 & 73.15 & 0.79 & 43.10 \\
\hline 8 & No. of fruits per plant & 11.22 & 34.22 & 20.35 & 35.10 & 34.64 & 27.48 & 27.30 & 98.70 & 12.04 & 55.87 \\
\hline 9 & Days to first harvest & 52.33 & 74.66 & 63.18 & 37.44 & 36.66 & 9.63 & 9.51 & 97.57 & 12.24 & 19.37 \\
\hline 10 & Days to last harvest & 132 & 165.66 & 150.57 & 92.80 & 92.29 & 6.39 & 6.38 & 99.42 & 19.73 & 13.10 \\
\hline 11 & Fruit length $(\mathrm{cm})$ & 5.02 & 18.42 & 11.93 & 11.96 & 11.69 & 28.98 & 28.65 & 97.69 & 6.96 & 58.33 \\
\hline 12 & Fruit width $(\mathrm{cm})$ & 2.77 & 7.73 & 5.12 & 1.78 & 1.76 & 26.06 & 25.90 & 98.73 & 2.71 & 53.02 \\
\hline 13 & Average fruit weight $(\mathrm{kg})$ & 0.04 & 0.16 & 0.10 & 0.35 & 0.30 & 36.74 & 36.69 & 99.75 & 0.07 & 75.49 \\
\hline 14 & Fruit yield per plant $(\mathrm{kg})$ & 0.71 & 2.94 & 2.00 & 1.40 & 1.39 & 49.66 & 49.49 & 99.31 & 2.12 & 101.61 \\
\hline 15 & $\begin{array}{l}\text { Ascorbic acid content } \\
(\mathrm{mg} / 100 \mathrm{~g})\end{array}$ & 3.27 & 9.52 & 6.29 & 2.06 & 2.03 & 22.79 & 22.66 & 98.91 & 2.92 & 46.44 \\
\hline 16 & $\begin{array}{l}\text { Total phenol content } \\
(\mathrm{mg} / 100 \mathrm{~g})\end{array}$ & 22.36 & 72.58 & 46.84 & 202.02 & 184.33 & 30.34 & 28.98 & 91.24 & 26.71 & 57.03 \\
\hline 17 & $\begin{array}{l}\text { Shoot and fruit borer } \\
\text { infestation }(\%)\end{array}$ & 7.88 & 36.56 & 16.41 & 48.60 & 45.95 & 42.46 & 41.28 & 94.54 & 13.57 & 82.70 \\
\hline 18 & $\begin{array}{l}\text { Cumulative wilt incidence } \\
(\%)\end{array}$ & 0.00 & 0.00 & 0.00 & 0.00 & 0.00 & 0.00 & 0.00 & 0.00 & 0.00 & 0.00 \\
\hline 19 & Little leaf incidence (\%) & 0.00 & 0.00 & 0.00 & 0.00 & 0.00 & 0.00 & 0.00 & 0.00 & 0.00 & 0.00 \\
\hline
\end{tabular}

In general, the values of PCV were higher than the values of GCV indicating that the apparent variation is not only due to genotypes but also due to influence of environment. Hence selection for the improvement of such characters will not be rewarding but the differences between PCV and GCV values were minimum, indicating that the traits under study were less influenced by environment.

The values of heritability in broad sense for the characters studied were high $(>60 \%)$, indicating that though the characters were least influenced by the environmental effects, the selection for the improvement of such characters may not be effective. The results agree with the findings of Lokesh et al., (2013). But heritability coupled with genetic advance as per cent of mean were more useful than heritability alone in predicting the resultant effect for selecting the best individual as explained by Johnson et al., (1955). In the present investigation, high heritability coupled with high genetic advance occurred for days to $50 \%$ flowering, 
number of flower clusters per plant, number of flowers per cluster, number of fruits per cluster, number of fruits per plant, days to last harvest, fruit length, fruit width, average fruit weight, fruit yield per plant, total phenol content, shoot and fruit borer infestation indicating that these characters are governed by additive genes and selection will be rewarding for the improvement of such traits. This result agrees with the findings of Shekar et al., (2012), Kumar et al., (2012), Arunkumar et al., (2013), Lokesh et al., (2013), Ramesh Kumar and Arumugam (2013), Gavade and Ghadage (2015).

High heritability accompanied with low genetic advance was noticed for ascorbic acid content indicating the role of non-additive gene action and selection for such traits may not be rewarding.

Burton (1952) stated that GCV together with high heritability and genetic advance would give the best picture on the extent of advance expected from selection. The genetic architecture of fruit yield is based on the balance, or overall net effect, produced by the interaction of yield components.

High estimates of PCV and GCV and high estimates of heritability coupled with high estimates of genetic advance for days to $50 \%$ flowering, number of flower clusters per plant, number of flowers per cluster, number of fruits per cluster, number of fruits per plant, days to last harvest, fruit length, fruit width, average fruit weight, fruit yield per plant, total phenol content, shoot and fruit borer infestation indicated that the variability available for these traits in the germplasm was high and selection for these traits may be effective. The promising accessions identified in this study could be used for prebreeding and other brinjal crop improvement programmes.

\section{References}

Arunkumar, B., Kumar, S.S.V. and Prakash, J.C. 2013. Genetic variability and divergence studies in brinjal (Solanum melongena L.). Bioinfolet, 10(2B): 739744.

Burton, G.W. 1952. Quantitative inheritance in grasses. Proc. 6th Int Grassland Cong., 1: 277-83.

Cochran, W.G., and G.M. Cox. 1957. Experimental Designs, pp. 127-131.

Dhankhar, B.S. and Singh, K. 1984. Path analysis for fruit yield and its components in brinjal (Solanum melongena L.). Haryana J. Hort. Sci., 12: 38-41.

Gavade, R.T. and Ghadage, B.A. 2015. Genetic variability, heritability and genetic advance in generation of brinjal (Solanum melongena L.). Bioinfolet., 12(1C): 325-328.

Johnson, H.W., Robinson, H.F. and Comstock, R.E. 1955. Estimates of genetic and environmental variability of Soybeans. Agron J., 47: 314-318.

Kumar, S., Sharma, J.P. and Chopra, S. 2011. Studies on variability, heritability and genetic advance for morphological and yield traits in brinjal (Solanum melongena L.). Mysore J. Agri. Sci., 45(1): 63-66.

Kumar, S.R., Arumugam, T. and Anandkumar, C.R. 2012. Genetic Diversity in Egg plant (Solanum melongena L.). Plant Gene Trait, 4(2): 4-8.

Lokesh, B., Reddy, S.P., Reddy, R.V.S.K. and Sivaraj, N. 2013. Variability, heritability and genetic advance studies in Brinjal (Solanum melongena L.). Electronic J. Plant Breed, 4(1): 10971100.

Lush, J.L. 1940. Inter-size correlation regression of offspring on dairy as a method of estimating heritability of 
characters. Proc. Amer. Soc., 33: 293301.

Ramesh Kumar, S. and Arumugam, T. 2013. Phenotypic evaluation of indigenous brinjal types suitable for rainfed conditions of South India (Tamil Nadu). Afr. J. Biotechnol., 12(27): 4338-4342.
Sivasubramanyam, M.S. and Menon, M.P. 1973. Path analysis of yield components in rice. Madras Agric. J., 60(9/12): 1217-1221.

Shekar, K.C., Ashok, P. and Shashikala. K. 2012. Studies on heritability and multivariate analysis in brinjal (Solanum melongena L.). Veg. Crop. Res. Bull., 76: 79-88.

\section{How to cite this article:}

Ravali, B., Ravinder Reddy, K., Saidaiah, P. and Shivraj, N. 2017. Variability, Heritability and Genetic Advance in Brinjal (Solanum melongena L.). Int.J.Curr.Microbiol.App.Sci. 6(6): 4247. doi: https://doi.org/10.20546/ijcmas.2017.606.004 